UDC 577.323:576.08

\title{
DNA loop organization in dorsal root ganglion neurons: effects of peripheral inflammation
}

\author{
K. S. Afanasieva1 ${ }^{1}$ D. E. Duzhyy ${ }^{2}$, P. V. Belan ${ }^{2}$, N. V. Voitenko², A. V. Sivolob ${ }^{1}$ \\ ${ }^{1}$ Educational and Scientific Center "Institute of Biology and Medicine", \\ Taras Shevchenko National University of Kyiv \\ 64/13, Volodymyrska Str., Kyiv, Ukraine, 01601 \\ ${ }^{2}$ O. O. Bogomoletz Institute of Physiology, NAS of Ukraine \\ 4, Akademika Bogomoltsa Str., Kyiv, Ukraine, 01004 \\ aphon@ukr.net
}

\begin{abstract}
The loop domain organization of chromatin plays an important role in transcription regulation and is known to be dependent on the cell functional states. The aim of this work was to investigate the possible DNA loop reorganization in dorsal ganglion neurons upon inflammatory pain. Methods. We used single cell gel electrophoresis (the comet assay) to analyze the kinetics of the DNA loop migration from the nucleoids obtained from lysed neurons. Results. Independently of inflammation, the neurons are characterized by relatively low amount of DNA in the comet tails due to a low content of DNA in the loops, which may be resolved by the comet assay (up to $\sim 400 \mathrm{~kb}$ ). Upon inflammation the contour length of the loops essentially decreases, in parallel with a respective increase of DNA in relatively short (up to $\sim 100 \mathrm{~kb}$ ) loops. Conclusions. The reorganization of the DNA loops upon inflammation could be suggested to be accompanied by rather significant changes in the transcription regulation.
\end{abstract}

Keyw or d s: DNA loops, neurons, comet assay, dorsal root ganglion, pain.

\section{Introduction}

Loop domains are known to be the key elements of both higher order chromatin structure and transcription regulation [1-5]. The loops, which appear in an active ATP-dependent process [6-8], are dynamic structures [9-11] and thus the loop organization is expected to vary under changes in the cell functional states.
Despite the comprehensive understanding of general principles of chromatin loop formation the reorganization of the loops upon functional transitions remains far from being completely understood.

In particular, to our knowledge, the chromatin loop domain organization in the nuclei

(C) 2021 K. S. Afanasieva et al.; Published by the Institute of Molecular Biology and Genetics, NAS of Ukraine on behalf of Biopolymers and Cell. This is an Open Access article distributed under the terms of the Creative Commons Attribution License (http://creativecommons.org/licenses/by/4.0/), which permits unrestricted reuse, distribution, and reproduction in any medium, provided the original work is properly cited 
of neurons has never been analyzed. In this communication we focused on dorsal root ganglion (DRG) neurons that are involved in pain reception. Under peripheral inflammation, DRG neurons are stimulated by inflammatory mediators, which sensitize neurons for pain perception by altering the expression of many genes [12-16]. Since changes in the expression of some genes during inflammation are associated with chromatin reorganization [17], it was interesting to assess the extent of such reorganization in DRG neurons caused by inflammation.

In our previous works we have developed a simple approach to test the loop domain organization (reviewed in [18]). The approach is based on an analysis of the electrophoretic track (the comet tail) formation in single cell gel electrophoresis (the comet assay). Measuring the kinetics of DNA exit during the comet assay we have shown that DNA loops in the nucleoids (cells lysed in the presence of detergents and high salt) correspond to chromatin loops in living cells [19-21]. We have shown also that the kinetic behavior of the two parameters, the relative amount of DNA in the comet tail and the tail length, depend on the cell type and/or the cell functional state [20, $22,23]$.

Here we investigate the loop domain organization in the DRG neurons obtained from the rats with and without peripheral inflammation. Our results show that, first, the loop domain organization is different in some aspects from that of the other cells previously investigated (lymphocytes, glioblastoma cells etc.), and, second, the loops in the DRG neurons are reorganized under peripheral inflammation.

\section{Materials and Methods}

Peripheral inflammation was induced by subcutaneous injection of about $100-150 \mu 1$ of complete Freund's adjuvant (CFA, Mycobacterium tuberculosis), suspended in an oil-saline (1:1) emulsion, into plantar side of one of two hind paw of the Wistar rats weighing $200+20$ g. The oil-saline (1:1) emulsion injection without CFA was done for the control in another paw. DRG neurons were isolated on the second day after injection.

Isolation of DRG neurons was done essentially as described previously [24]. Lumbar L4-L6 DRG neurons were collected in the $1.5 \mathrm{ml}$ Eppendorf tubes with $1 \mathrm{ml}$ of Tyrode's solution containing $0.3 \%$ type 4 collagenase $250 \mathrm{U} / \mathrm{mg}$ (Worthington, USA) and $0.3 \%$ trypsin, $204 \mathrm{U} / \mathrm{mg}$ (Worthington, USA), treated for $20 \mathrm{~min}$ at $36^{\circ} \mathrm{C}$, washed from enzymes in fresh Tyrode's solution and mechanically dissociated by triturating them through a series of Pasteur pipettes polished to several narrowing diameters. Isolated cells were collected by centrifugation, resuspended in fresh Tyrode's solution and kept in refrigerator at $4{ }^{\circ} \mathrm{C}$ until use. Undissociated ganglia were collected in a tube with a fresh reaction mixture and procedure of the neurons isolation was repeated until complete dissociation of ganglia.

The comet assay was performed as described earlier [19, 20, 25]. Briefly, neurons were embedded in the $0.67 \%$ agarose gel on the surface of a microscope slide. Slides were treated with ice-cold lysis solution $(2.5 \mathrm{M}$ $\mathrm{NaCl}, 100 \mathrm{mM}$ EDTA, $10 \mathrm{mM}$ Tris-HCl (pH 8.0), $1 \%$ Triton X-100) for several hours, washed twice by TBE buffer ( 89 MMTrisborat, 2 мM EDTA, pH 7.5) and electrophoresed in the same buffer. Several slides, which 
were simultaneously prepared in the same way, were placed into the electrophoresis tank, and then they were taken out every 10 minutes of electrophoresis. After electrophoresis the slides were stained with DAPI and immediately analyzed with a fluorescent microscope. A total 100-150 randomly chosen nucleoids on each slide were examined using image analysis software CometScore (TriTec, USA) to determine the relative amount of DNA in the tails and the tail length. Taking the contour length of the loop to be roughly two times longer than the extended loop, the tail length was multiplied by two and divided by $0.34 \mathrm{~nm}$ (the distance between the adjacent base pairs) to convert it in the contour length (in base pairs) of the longest loops. The kinetic plots of the relative amount $F$ of DNA in the tails versus electrophoresis time $t$ were fitted according to the standard equation of monomolecular kinetics [19]:

$$
F=F_{m}(1-\exp (-k t))
$$

where $F_{m}$ is the maximum relative amount of DNA that can exit, $k$ is the rate constant.

\section{Results and Discussion}

Fig. 1A,B shows the kinetics of the comet tail formation during the comet assay that was done with DRG neurons obtained from control rats and rats with peripheral inflammation. As compared with other cell types investigated earlier, the plots are different in some respects. Our previous analysis allowed us to divide all the nucleoid loops into three subsets: loops on the nucleoid surface, which migrate very rapidly; inner loops inside the nucleoid, the migration of which is retarded; and very large
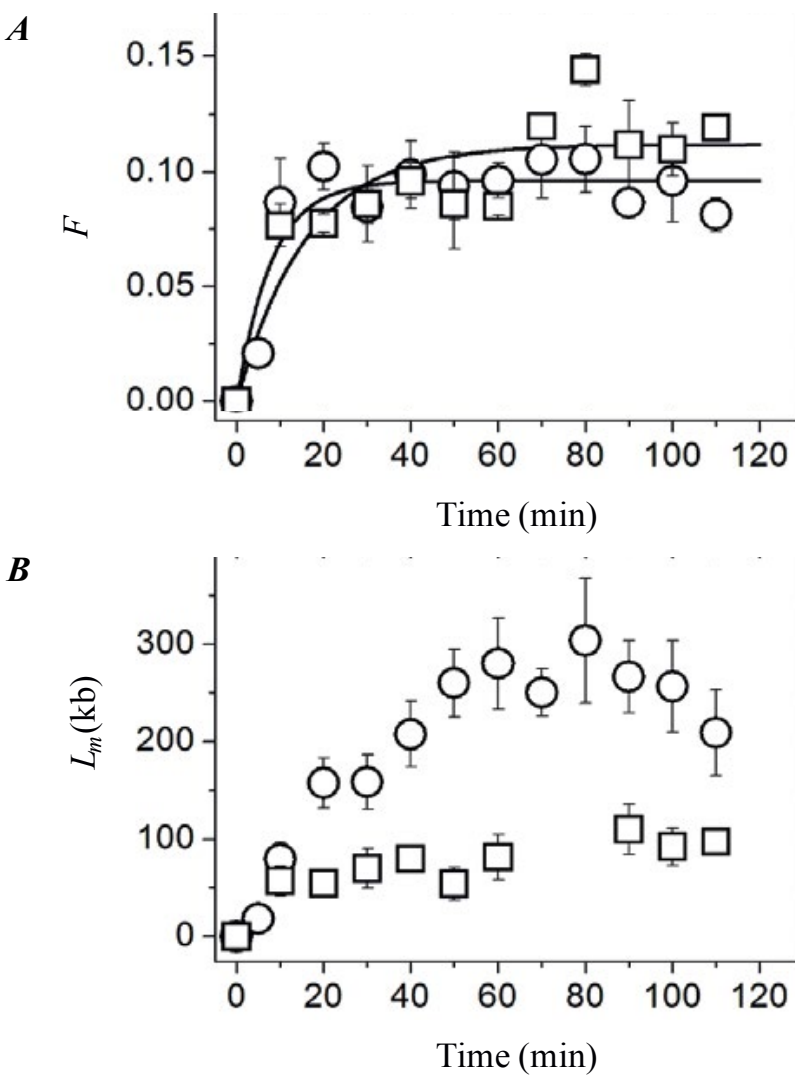

Fig. 1. The average relative amount $F$ of DNA in the comet tails (A) and the average contour length of the longest loops $L_{\mathrm{m}}$ in the tails (B) as functions of electrophoresis time for nucleoids obtained from DRG neurons of control rats $(\circ)$ and rats with inflammation $(\square)$.

loops (longer than $\sim 400 \mathrm{~kb}$ ) that cannot migrate at all $[19,26]$. After a long-time electrophoresis the relative amount of DNA in the tails reached $\sim 20 \%$ (first two subsets together) for human lymphocytes [19]. For less differentiated cancer cells of different types the saturation level of DNA in the tails was much lower $[20,22,23]$, i.e., there was a large amount of DNA in the very long loops. At the same time, the kinetic plots of DNA exit usually had a two-step shape (the two steps were attributed to first two subsets of the loops 
mentioned above) $[19,20,22,23]$. Low saturation levels in the relative DNA amount plots

A

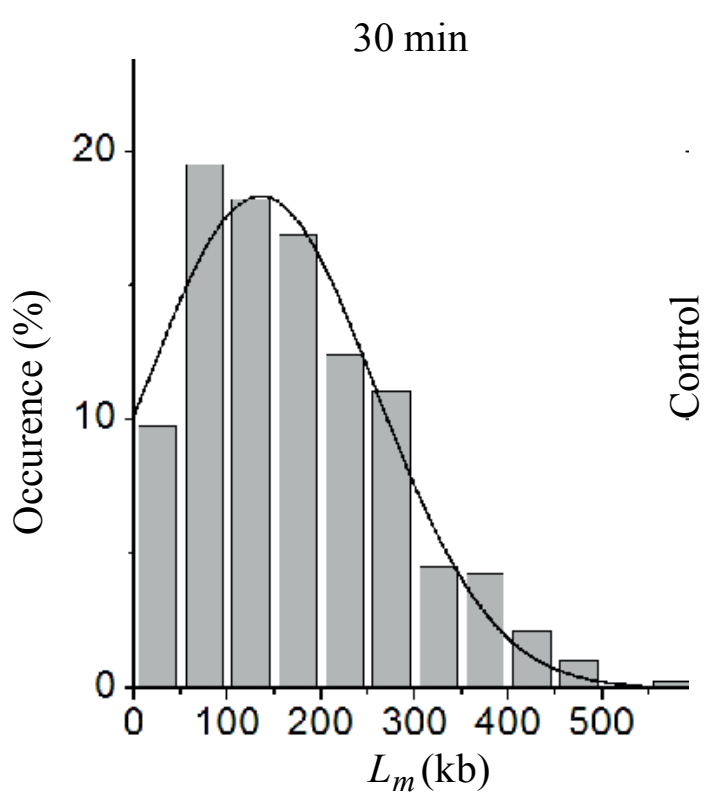

C

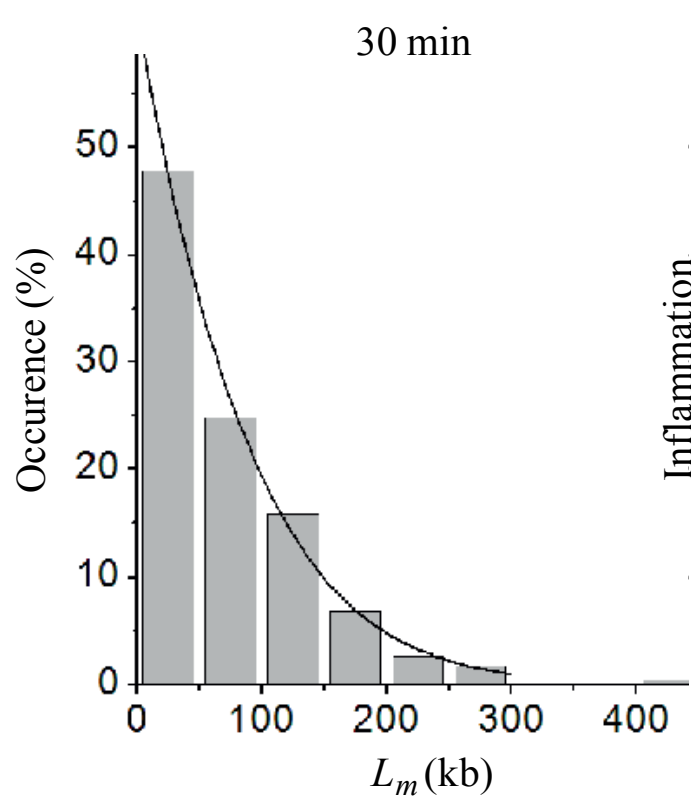

(Fig. 1A) resemble those of the cancer cells. But, in contrast to many other cells studied

$\boldsymbol{B}$

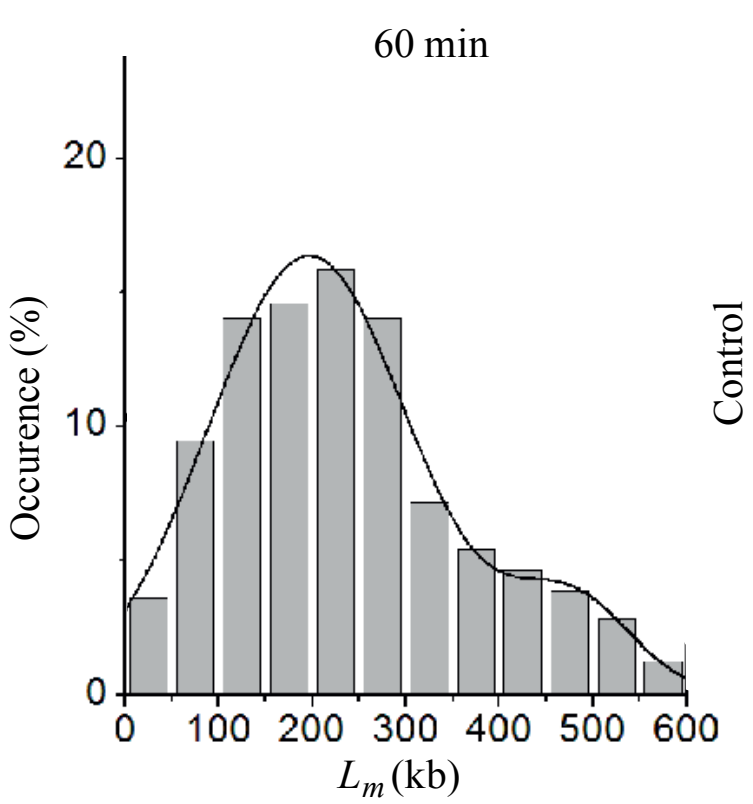

D

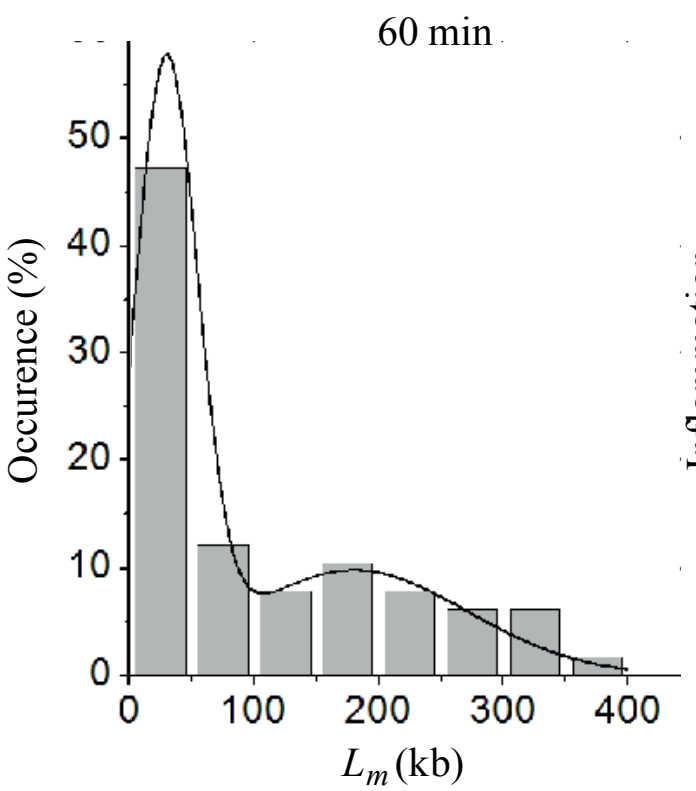

Fig. 2. Distributions of the contour length of the longest loops $L_{\mathrm{m}}$ in the tails fitted by Gaussians (smooth curves) after $30 \min (\mathrm{A}, \mathrm{C})$ and $60 \mathrm{~min}(\mathrm{~B}, \mathrm{D})$ electrophoresis for nucleoids obtained from DRG neurons of control rats $(\mathrm{A}, \mathrm{B})$ and rats with inflammation $(\mathrm{C}, \mathrm{D})$. 
before, the second step was absent: the plots can be fitted with the standard equation (Eq. 1) of monomolecular kinetics (Fig. 1A). It can be concluded that the tail of the neuronal nucleoids is formed exclusively by the surface loops whereas the inner loops are too large to be resolved by the comet assay. Moreover, this feature does not change under inflammation: the two plots in Fig. 1A are almost the same.

In contrast to the kinetic behavior of the DNA relative amount in the tails, the tail length was found to be sensitive to inflammation. Induction of inflammatory pain resulted in an essential decrease in the contour length of the longest loops (Fig. 1B): during inflammatory process the loops larger than $\sim 100 \mathrm{~kb}$, which were present in control nucleoids, disappeared. Since the relative amount of DNA in the tails does not change under inflammation, it should mean that the number of short loops essentially increases.

We have analyzed also the longest loop length distributions at different moments during electrophoresis (Fig. 2). After a relatively short electrophoresis (up to $30 \mathrm{~min}$ ) the distributions can be fitted by single Gaussians (Fig. 2A,C). This was not the case, however, after more prolonged electrophoresis when the distributions became biphasic (Fig 2B, D). This observation shows that longer loops (probably located inside the nucleoids) can exit during long-time electrophoresis but their contribution into the average values presented in Fig. 1B is not so large. Altogether, our results clearly show that rearrangements of the DNA loops occur in DRG neurons under the induction of inflammatory pain. Such rearrangements are probably accompanied by essential changes in the transcription regulation system.

\section{Conclusions}

The results of our analysis of the kinetics of electrophoretic track formation for the nucleoids derived from DRG neurons can be summarized as follows. (1) A relatively low amount of DNA in the tails after a long-time comet assay seems to be a signature of the neuron-derived nucleoids. The main reason of this is a low content of DNA in the loops, the sizes of which are within the resolution of the comet assay (up to $\sim 400 \mathrm{~kb}$ ). (2) The inflammation does not change this low amount of DNA but induces a redistribution of the loops: the contour length of the loops resolved by the comet assay essentially decreases, obviously in parallel with an increase of DNA in such relatively short loops (up to $\sim 100 \mathrm{~kb}$ ). The results of this work suggest that the DNA loop reorganization under inflammation should be accompanied by rather significant changes in the transcription regulation.

\section{Acknowledgments}

This work was supported by the Branch of Target Training of Taras Shevchenko National University and National Academy of Sciences of Ukraine (Grant 0117U006347) and by the National Academy of Sciences of Ukraine grants №0116U004470 and №0120U00 to PB and NV.

\section{REFERENCES}

1. Dekker J, Marti-Renom MA, Mirny LA. Exploring the three-dimensional organization of genomes: interpreting chromatin interaction data. Nat Rev Genet. 2013;14(6):390-403.

2. Gibcus JH, Dekker J. The hierarchy of the 3D genome. Mol Cell. 2013;49(5):773-82.

3. Dekker J, Mirny L. The 3D Genome as Moderator of Chromosomal Communication. Cell. 2016;164(6): 1110-21. 
4. Dixon JR, Gorkin DU, Ren B. Chromatin Domains: The Unit of Chromosome Organization. Mol Cell. 2016;62(5):668-80.

5. Rao SS, Huntley MH, Durand NC, Stamenova EK, Bochkov ID, Robinson JT, Sanborn AL, Machol I, Omer AD, Lander ES, Aiden EL. A 3D map of the human genome at kilobase resolution reveals principles of chromatin looping. Cell. 2014;159(7): 1665-80.

6. Sanborn AL, Rao SS, Huang SC, Durand NC, Huntley $M H$, Jewett AI, Bochkov ID, Chinnappan D, Cutkosky A, Li J, Geeting KP, Gnirke A, Melnikov A, McKenna D, Stamenova EK, Lander ES, Aiden EL. Chromatin extrusion explains key features of loop and domain formation in wild-type and engineered genomes. Proc Natl Acad Sci U S A. 2015;112(47): E6456-65.

7. Fudenberg $G$, Imakaev $M, L u$, Goloborodko A, Abdennur N, Mirny LA. Formation of Chromosomal Domains by Loop Extrusion. Cell Rep. 2016;15(9):2038-49.

8. Vian L, Pękowska A, Rao SSP, Kieffer-Kwon KR, Jung S, Baranello L, Huang SC, El Khattabi L, Dose M, Pruett N, Sanborn AL, Canela A, Maman Y, Oksanen A, Resch W, Li X, Lee B, Kovalchuk AL, Tang Z, Nelson S, Di Pierro M, Cheng RR, Machol I, St Hilaire BG, Durand NC, Shamim MS, Stamenova EK, Onuchic JN, Ruan Y, Nussenzweig A, Levens D, Aiden EL, Casellas R. The Energetics and Physiological Impact of Cohesin Extrusion. Cell. 2018;173(5):1165-1178.e20.

9. Hansen AS, Cattoglio C, Darzacq X, Tjian R. Recent evidence that TADs and chromatin loops are dynamic structures. Nucleus. 2018;9(1):20-32.

10. Nora EP, Goloborodko A, Valton AL, Gibcus JH, Uebersohn A, Abdennur N, Dekker J, Mirny LA, Bruneau $B G$. Targeted Degradation of CTCF Decouples Local Insulation of Chromosome Domains from Genomic Compartmentalization. Cell. 2017;169(5):930-944.e22.

11. Hansen AS, Hsieh TS, Cattoglio C, Pustova I, Saldaña-Meyer R, Reinberg D, Darzacq X, Tjian R. Distinct Classes of Chromatin Loops Revealed by Deletion of an RNA-Binding Region in CTCF. $\mathrm{Mol}$ Cell. 2019;76(3):395-411.e13. d
12. Gould HJ 3rd, England JD, Soignier RD, Nolan P, Minor LD, Liu ZP, Levinson SR, Paul D. Ibuprofen blocks changes in $\mathrm{Na} v 1.7$ and 1.8 sodium channels associated with complete Freund's adjuvant-induced inflammation in rat. J Pain. 2004;5(5):270-80.

13. Voilley N, de Weille J, Mamet J, Lazdunski M. Nonsteroid anti-inflammatory drugs inhibit both the activity and the inflammation-induced expression of acid-sensing ion channels in nociceptors. $J \mathrm{Neu}$ rosci. 2001;21(20):8026-33.

14. Ikeda-Miyagawa Y, Kobayashi K, Yamanaka $H$, Okubo M, Wang S, Dai Y, Yagi H, Hirose M, Noguchi $K$. Peripherally increased artemin is a key regulator of TRPA1/V1 expression in primary afferent neurons. Mol Pain. 2015;11:8.

15. Schwartz ES, Xie A, La JH, Gebhart GF. Nociceptive and inflammatory mediator upregulation in a mouse model of chronic prostatitis. Pain. 2015; 156(8): 1537-44.

16. Belan PV, Usachev YM, Duzhyy DE, Ivanova SY, Tarasenko AN, Voitenko NV. Role of T-type Ca2+ channels in painful diabetic neuropathy. Neurophysiology. 2019; 51:455-61.

17. Czimmerer Z, Horvath A, Daniel B, Nagy G, Cuaranta-Monroy I, Kiss $M$, Kolostyak $Z$, Poliska $S$, Steiner L, Giannakis N, Varga T, Nagy L. Dynamic transcriptional control of macrophage miRNA signature via inflammation responsive enhancers revealed using a combination of next generation sequencing-based approaches. Biochim Biophys Acta Gene Regul Mech. 2018;1861(1):14-28.

18. Afanasieva K, Sivolob A. Physical principles and new applications of comet assay. Biophys Chem. 2018;238:1-7.

19. Afanasieva K, Chopei $M$, Zazhytska M, Vikhreva $M$, Sivolob $A$. DNA loop domain organization as revealed by single-cell gel electrophoresis. Biochim Biophys Acta. 2013;1833(12):3237-44.

20. Afanasieva K, Chopei M, Lozovik A, Semenova A, Lukash L, Sivolob A. DNA loop domain organization in nucleoids from cells of different types. Biochem Biophys Res Commun. 2017;483(1):142-6.

21. Afanasieva $K S$, Olefirenko $V V$, Sivolob $A V$. DNA loops after cell lysis resemble chromatin loops in an intact nucleus. Ukr Biochem J. 2018; 90(5):43-9. 
22. Afanasieva KS, Semenova AY, Lukash LL, Sivolob $A V$. DNA loop organization in glioblastoma T98G cells at their different functional states. Biopolym Cell. 2018;34(6):426-34.

23. Afanasieva K, Olefirenko A, Martyniak A, Lukash L, Sivolob A. DNA loop domain rearrangements in blast transformed human lymphocytes and lymphoid leukaemic Jurkat T cells. Ukr Biochem J. 2020;92(5): 62-9.

24. Duzhyy DE, Viatchenko-Karpinski VY, Khomula EV, Voitenko NV, Belan PV. Upregulation of T-type $\mathrm{Ca} 2+$ channels in long-term diabetes determines increased excitability of a specific type of capsaicin-insensitive DRG neurons. Mol Pain. 2015;11:29.

25. Afanasieva K, Zazhytska M, Sivolob A. Kinetics of comet formation in single-cell gel electrophoresis: loops and fragments. Electrophoresis. 2010;31(3): 512-9.

26. Afanasieva K, Chopei M, Sivolob A. Single nucleus versus single-cell gel electrophoresis: kinetics of DNA track formation. Electrophoresis. 2015;36(78):973-7.

\section{Організація петельних доменів ДНК в нейронах дорсальних корінцевих гангліїв: ефекти периферичного запалення}

К. С. Афанасьєва, Д. Е. Дюжий, П. В. Білан, Н. В. Войтенко, А. В. Сиволоб

Резюме. Організація петельних доменів хроматину, що відіграє важливу роль у регуляції транскрипції, залежить від функціонального стану клітини. Мета роботи полягала у дослідженні можливої реорганізації петель ДНК у нейронах дорсальних корінцевих гангліїв при індукції запального болю. Методи. Ми використовували електрофорез ізольованих клітин (кометний електрофорез) для аналізу кінетики міграції петель ДНК із нуклеоїдів, отриманих з лізованих нейронів. Результати. Незалежно від запалення, нейрони характеризуються відносно низьким рівнем ДНК у хвостах комет внаслідок низького вмісту ДНК у петлях, що знаходяться у межах роздільної здатності кометного електрофорезу (до 400 кб). За умов запалення контурна довжина петель суттєво знижується, паралельно із відповідним зростанням частки ДНК у складі відносно коротких (до 100 кб) петель. Висновки. Можна припустити, що реорганізація петель ДНК при запаленні повинна супроводжуватись 3 вельми суттєвими змінами у регуляції транскрипції.

К л юч о в і с л о в а: петлі ДНК, нейрони, кометний електрофорез, дорсальні корінцеві ганглії, біль.

\section{Организация петельных доменов ДНК} в нейронах дорсальных корешковых ганглиев: эффекты периферического воспаления

\author{
К. С. Афанасьева, Д. Е. Дюжий, П. В. Белан, \\ Н. В. Войтенко, А. В. Сиволоб
}

Резюме. Организация петельных доменов хроматина, играющая важную роль в регуляции транскрипции, зависит от функционального состояния клетки. Цель работы заключалась в исследовании возможной реорганизации петель ДНК в нейронах дорсальных корешковых ганглиев при индукции воспалительной боли. Методы. Мы использовали электрофорез изолированных клеток (кометный электрофорез) для анализа кинетики миграции петель ДНК из нуклеоидов, полученных из лизированных нейронов. Результаты. Независимо от воспаления, нейроны характеризуются относительно низким уровнем ДНК в хвостах комет из-за низкого содержания ДНК в петлях, которые находятся в пределах разрешающей способности кометного электрофореза (до 400 кб). В условиях воспаления контурная длина петель существенно уменьшается, параллельно с соответствующим возрастанием доли ДНК в составе относительно коротких (до 100 кб) петель. Выводы. Можно предположить, что реорганизация петель ДНК при воспалении должна быть ассоциирована с довольно существенными изменениями в регуляции транскрипции.

Кл юч е в ы е с л о в а: петли ДНК, нейроны, кометный электрофорез, дорсальные корешковые ганглии, боль.

Received 31.12.2020 